\title{
CONJUNCTIVAL MICROBIAL FLORA OF CLINICALLY NORMAL PERSONS WHO WORK IN A HOSPITAL ENVIRONMENT
}

\author{
Rita de Cássia Trindade ${ }^{1}$; Ana Cristina Rocha Bonfim ${ }^{1}$; Maria Aparecida Resende ${ }^{*}$ \\ ${ }^{1}$ Centro de Ciências Biológicas e da Saúde, Universidade Federal de Sergipe, São Cristóvão, SE, Brasil. \\ ${ }^{* 2}$ Instituto de Ciências Biológicas, Universidade Federal de Minas Gerais, Belo Horizonte, MG, Brasil.
}

Submitted: February 09, 1999; Approved: February 02, 2000

\begin{abstract}
The objective of the work was to study the microbiota of the conjunctival secretion of health professionals. Samples were collected from the clinically normal eyes of 40 health professionals in four different sectors, Proctology, General Intensive Care Unit (ICU), Male Ward, and Oncology of Hospital das Clínicas Dr. Augusto Leite, Aracaju, SE, Brazil. Ten professionals from each sector were selected. The samples were inoculated into various culture media: blood agar, Chapman agar, EMB medium (Teague), and Sabouraud dextrose agar with chloramphenicol. The bacteria most frequently isolated from all the sectors were Staphylococcus epidermidis (45.0\%) and Bacillus sp (29.0\%). The least frequent bacteria were Proteus sp (6.1\%), Staphylococcus aureus (4.1\%), Enterobacter sp (4.1\%), Alcaligenes sp (4.1\%), Citrobacter $\mathrm{sp}(2.1 \%)$, Moraxella sp (2.1\%), and Proteus mirabilis (2.1\%). Fungi were not isolated. These results confirm the continuous contamination of the conjunctival sac of these professionals by the external environment, while at the same time confirming that the mechanisms of local defence continue to be intact, preventing the fixation of invading microorganisms.
\end{abstract}

Key words: conjunctival microbiota, hospital environment, Staphylococcus epidermidis, Staphylococcus aureus

\section{INTRODUCTION}

The eye is a paired organ located in the orbital cavity whose function is to capture images that are sent to the cortical vision center (1). The following structures protect the eye: conjunctiva, eyelids, and lacrimal apparatus (14). The conjunctiva is a thin, transparent, smooth and humid membrane that covers and protects the anterior portion of the sclera (bulbar conjunctiva) and the inner part of the eyelids (palpebral conjunctiva) (14).

The conjunctiva has a peculiar resident microbiota predominantly consisting of diphtheroids (Corinebacterium xerosis), Neisseria, Haemophilus-like Gram-negative bacilli (Morax-Axenfeld bacillus, a Moraxella species), staphylococci and non-hemolytic streptococci. The normal microbiota also includes Staphylococcus aureus, Propionibacterium sp,
Peptococcus sp, Peptostreptococcus sp, Clostridium sp, Fusarium sp, and Cephalosporium sp $(2,3,5,6,7,8,9,11,12$, $13,18)$. When changes occur in the environment, commonly occurring microorganisms may temporarily become part of the transitory conjunctival microbiota, without causing damage. However, when a break occurs in the equilibrium between the resident and transitory microbiota, diseases may arise. These modifications mainly result from the indiscriminate use of eye drops containing antimicrobial agents or corticoids. Corticosteroids, in turn, by reducing host resistance may increase the virulence of species known to be pathogenic and may permit other species considered to be commensal to manifest virulence (16).

Because of its constant exposure to the external medium, the conjunctiva is subject to intense microbial contamination.

\footnotetext{
* Corresponding author. Mailing address: Departamento de Microbiologia, ICB/UFMG, Av. Antonio Carlos, 6627, CEP 31270-901, Belo Horizonte, MG, Brasil. Fax: (+5531) 499-2730, E mail: maresend@mono.icb.ufmg.br
} 
Most microorganisms are removed by lacrimation, with only a relatively low-density microbiota being left behind, consisting of a reduced number of species (20).

The control of ocular invasion by fungi, Gram-negative rods and bacterial of low pathogenicity depends largely on the mechanisms of immunity (16). The eye is constantly bathed by tears, a fluid consisting of components such as lysozyme, lactoferrin, beta-lysine and IgG. The synergistic combination of these components has the ability to destroy bacteria, explaining the recognized antibacterial action of tears. Tears, in addition to representing a poor culture medium, mainly act in a mechanical manner, removing most of the microorganisms that invade the conjunctiva or the surface of the ocular globe through the lacrimal ducts towards the nasal fossae.

Bacteriologic investigations of clinically normal human eyes has demonstrated that the resident microbiota in the conjunctival sac is similar to the microbiota of nearby structures $(9,11,12$, 15), with an exchange occurring between these floras (11), although the levels of viable microorganisms may be quite low in the conjunctiva (9).

Human beings - patients, hospital staff and visitors - represent the primary reservoir of normal human microbiota in the hospital. The secondary reservoirs of these microorganisms include all environments in which nutrients, humidity and temperature are adequate for their survival, such as hydrotherapy and dialysis equipment, equipment fitted with air humidifiers, nebulizers of all types, food kept at room temperature or at inappropriate temperatures, and others (20).

Contact of the infectious agent with the host may be direct, indirect or by the projection of droplets (20). Direct contact is established through contaminated hands. Transmission by indirect contact occurs when the infectious agent contaminates various objects, which later come into contact with the mouth, ocular conjunctiva, skin or mucosae of the host (20). Mucus particles or saliva droplets directly expelled when a person sneezes, coughs or speaks represent a modality of transmission by direct contact since they imply an intimate association between two or more persons.

Transmission through a common vehicle, when the infectious agent goes from its reservoir to more than one host, usually occurs due to contamination of food, water, blood, intravenous solutions or germicidal preparations (20).

Pseudomonas, Flavobacterium, Acinetobacter, Serratia, Enterobacter and Klebsiella can actively multiply in water, and Pseudomonas can reproduce even in distilled water (20).

Hospitals should be considered insalubrious by definition. They differ from other habitats by the intensive use of chemotherapeutic antibiotics which select multiresistant samples normally not encountered in the community (20).

Therefore it is important to study the modifications that occur at the conjunctival microbial flora level in persons who work in the hospital environment.
The objective of the present investigation was to study the microbiota of the conjunctival secretion of health professionals and to determine its changes by comparing it to the microbiota of persons who do not work in a hospital environment, as reported in the literature.

\section{MATERIALS AND METHODS}

Isolation and identification of the microorganisms. Samples were collected from the clinically normal eyes of 40 health professionals (physicians, nurses and nursing attendants) in four different sectors (Proctology, General Intensive Care Unit, Male Ward, and Oncology) of Hospital das Clínicas Dr. Augusto Leite, Aracaju, SE, Brazil. Ten professionals from each sector were selected at random on a volunteer basis. The material was collected with sterile cotton swabs and transported in tubes containing $0.83 \%$ saline solution at room temperature. A direct examination was immediately performed using Gram and AlbertLaybourn stains. New samples were collected from only 8 of the 12 volunteers showing alterations in the microbiota. The material was inoculated into various culture media: blood agar, Chapman agar, and EMB medium (Teague-Difco). Plates were cultured at $37^{\circ} \mathrm{C}$ and observed daily over a period of 48 hours. Plates containing Sabouraud dextrose agar with chloramphenicol were inoculated and incubated at $28^{\circ} \mathrm{C}$ and observed over a period of two weeks for the determination of the development of fungi. After culture the colonies were replated into tubes containing slanted simple agar, or glucose broth according to the presumptive identification of the group, and left to grow at $37^{\circ} \mathrm{C}$ for 24 hours. Gram staining was then performed. After Gram staining the isolates were divided into Gram-negative bacilli, Gram-negative diplobacilli, Gram-positive bacilli, and Gram-positive cocci and submitted to the appropriate biochemical tests for identification. The isolated taxa were identified according to classical keys and tables available in the literature.

\section{RESULTS}

Among the 40 volunteers tested, $18(45.0 \%)$ presented positive microbial growth. Ten $(55.5 \%)$ presented only one genus, $2(11.1 \%)$ presented two genera, $3(16.6 \%)$ three genera, $2(11.1 \%)$ four genera, and $1(22.2 \%)$ five different genera of bacteria.

The bacteria most frequently isolated from all the sectors were Staphylococcus epidermidis (45.0\%) and Bacillus sp (29.0\%). The least frequent bacteria were Proteus sp (6.1\%), Staphylococcus aureus (4.1\%), Enterobacter sp (4.1\%), Alcaligenes sp (4.1\%), Citrobacter sp (2.1\%), Moraxella sp (2.1\%), and Proteus mirabilis (2.1\%) (Table 1).

The bacteria most frequently isolated from the Sector of 
Table 1- Frequency (\%) and total number of the bacteria isolated from conjunctival secretion of health professionals in four sectors of the Hospital das Clínicas Dr. Augusto Leite

\begin{tabular}{lcccccc}
\hline Isolate & \multicolumn{5}{c}{ Single and combined frequency (\%) and number of isolates } \\
& Proctology & Oncology & General ICU & Male Ward & CF (\%) & TNI \\
\hline Staphylococcus epidermidis & 44.4 & 25.0 & 40.0 & 75.0 & 45.0 & 22 \\
Bacillus $\mathrm{sp}$ & 25.0 & 50.0 & 40.0 & 25.0 & 29.0 & 14 \\
Proteus $\mathrm{sp}$ & 8.3 & 0 & 0 & 0 & 6.1 & 3 \\
Staphylococcus aureus & 5.5 & 0 & 0 & 0 & 4.1 & 2 \\
Enterobacter $\mathrm{sp}$ & 5.5 & 0 & 0 & 0 & 4.1 & 2 \\
Alcaligenes $\mathrm{sp}$ & 5.5 & 0 & 0 & 0 & 4.1 & 2 \\
Proteus mirabilis & 2.7 & 25.0 & 0 & 0 & 4.1 & 2 \\
Citrobacter $\mathrm{sp}$ & 2.7 & 0 & 0 & 0 & 2.1 & 1 \\
Moraxella $\mathrm{sp}$ & 0 & 0 & 20.0 & 0 & 2.1 & 1 \\
\hline
\end{tabular}

CF: Combined frequency

TNI: Total number of isolations

Proctology was $S$. epidermidis (44.4\%), followed by Bacillus $\mathrm{sp}(25.0 \%)$, Proteus sp (8.3\%), S. aureus, Enterobacter sp, and Alcaligenes sp (5.5\%). Proteus mirabilis and Citrobacter sp were the least frequent bacteria (2.7\%) (Fig. 1). Bacillus sp and S. epidermidis (40\%), were the most frequent microorganisms isolated in the General ICU followed by Moraxella sp (20.0\%) (Fig. 2). In the Male Ward only S. epidermidis $(75.0 \%)$ and Bacillus sp (25.0\%) were isolated (Fig. 3). In the Sector of Oncology the most frequent bacteria isolated was Bacillus sp (50.0\%) followed by Proteus mirabillis and S. epidermidis (25.0\%) (Fig. 4).

Only three subjects among eight repeated samples showed alterations involving bacteria of different genera (Table 2).

Fungi were not isolated.

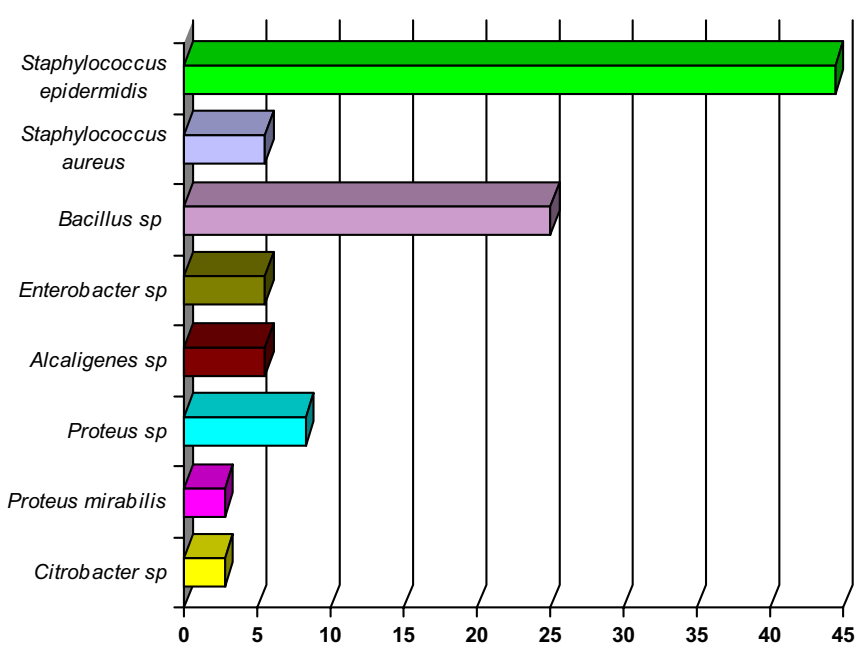

Figure 1. Frequency (\%) of the bacteria isolated from the conjuctiva in the sector of Proctology.

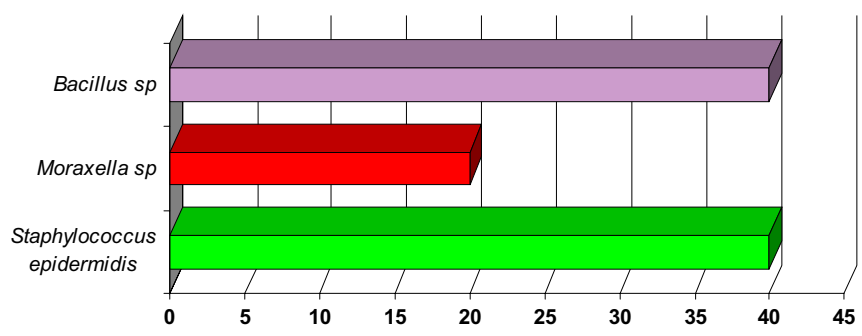

Figure 2. Frequency (\%) of the bacteria isolated from the conjuctiva in General ICU.

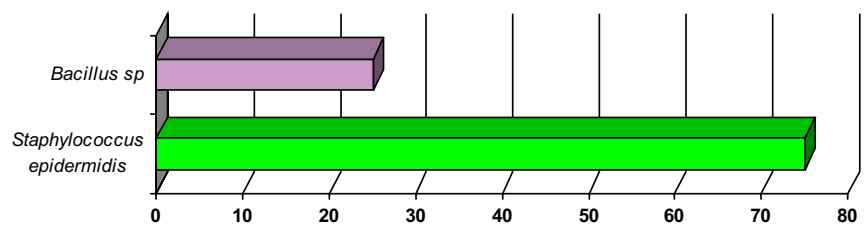

Figure 3. Frequency (\%) of the bacteria isolated from the conjuctiva in the Male Ward.

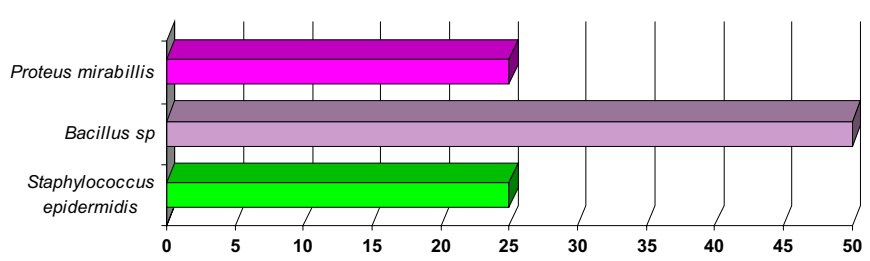

Figure 4. Frequency ( $\%$ ) of the bacteria isolated from the conjunctiva in the Oncology Ward 
Table 2. Frequency (\%) and total number of the bacteria isolated from eight volunteers showing previous alterations in their conjunctival microbiota

\begin{tabular}{|c|c|c|c|c|c|c|c|c|c|c|c|c|c|c|}
\hline \multirow{3}{*}{ Isolate } & \multicolumn{13}{|c|}{ Number of isolates and frequency (\%) } & \multirow{3}{*}{$\begin{array}{c}\text { Frequency } \\
(\%)\end{array}$} \\
\hline & \multicolumn{3}{|c|}{ Proctology } & \multicolumn{3}{|c|}{ General ICU } & \multicolumn{3}{|c|}{ Male Ward } & \multicolumn{3}{|c|}{ Oncology } & \multirow{2}{*}{$\begin{array}{c}\text { Total } \\
\text { number }\end{array}$} & \\
\hline & $\mathrm{L}$ & $\mathrm{P}$ & $\mathrm{T}$ & $\mathrm{L}$ & $\mathrm{P}$ & $\mathrm{T}$ & $\mathrm{L}$ & $\mathrm{P}$ & $\mathrm{T}$ & $\mathrm{L}$ & $\mathrm{P}$ & $\mathrm{T}$ & & \\
\hline Staphylococcus epidermidis & 02 & - & 02 & - & - & - & - & - & - & - & - & - & 02 & 25 \\
\hline Staphylococcus aureus & 01 & 01 & 02 & - & - & - & - & - & - & - & - & - & 02 & 25 \\
\hline Alcaligenes sp & - & 01 & 01 & - & - & - & - & - & - & 01 & - & 01 & 02 & 25 \\
\hline Enterobacter $\mathrm{sp}$ & 01 & - & 01 & 01 & - & 01 & - & - & - & 01 & - & 01 & 02 & 25 \\
\hline Total & 04 & 02 & 06 & - & - & - & - & - & - & 02 & - & 02 & 08 & 100 \\
\hline
\end{tabular}

L: Last collection

P: Previous collection

T: Total of isolates

\section{DISCUSSION}

The high frequency of Staphylococcus epidermidis isolated from conjunctival secretion confirms the data obtained by most authors $(3,5,8,13)$ and the data obtained in a study with 45 students of the basic cycle of the Centro de Ciências Biológicas e da Saúde of the Universidade Federal de Sergipe, without any contact with hospital environment (20). Staphylococcus epidermidis was the only bacteria isolated from twenty students $(44.4 \%)$ of the group studied.

The bacteria of the genus Bacillus and of the genus Enterobacter detected here, as well as Alcaligenes sp, Proteus sp, Proteus mirabilis and Citrobacter sp, are not cited in the literature as belonging to the normal conjunctival microbiota. Fahmy et al. (4), in a study of the conjunctival microbiota of the normal eyes of 200 subjects, isolated Gram-negative bacilli (Escherichia coli, Pseudomonas aeruginosa, Klebsiella pneumoniae, Proteus morgani, Bacterium nitratum, and Enterobacter (loacae) which they considered to belong to the normal conjunctival microbiota. These investigators, however, did not consider the occupation of each subject.

Of the 18 positive samples (corresponding to 18 employees in the 4 sectors of the hospital), 12 showed a modified conjunctival microbiota compared to the composition considered normal on the basis of the literature, and on the results obtained for one group of students (6). In this group, considered for us as control group, only $S$. epidermidis was detected in the conjunctival sac of the subjects.

In the present study, a new collection could be obtained from only 8 of the 12 volunteers showing alterations in their conjunticval microbiota since the remaining four employees no longer worked in the same institution. The objective of the repeated collection was to determine the maintenance of the alterations observed and thus conclude this stage of the study. Of the 8 repeated samples, only 3 showed alterations involving bacteria of different genera compared to those isolated in the previous collection (Table 2). These results confirm the continuous contamination by the external environment, while at the same time confirming that the mechanisms of local defence continue to be intact, preventing the fixation of invading microorganisms. However, any type of immunologic disequilibrium may trigger serious infections of difficult treatment since exposure is continuous and the microbiota of the hospital environment is peculiar and rich in pathogens especially resistant to several chemotherapeutic agents.

Recent studies on persons who use contact lenses have detected quantitative alterations in the conjunctival microbiota $(3,10,17,19)$. This finding should motivate research on the extent of alteration in persons who work in hospital environments and use contact lenses since the constant exposure to this environment may cause quantitative changes which, added to qualitative changes imposed by the use of the lenses, may increase the possibility of developing diseases.

\section{ACKNOWLEDGEMENTS}

We thank CNPq (Conselho Nacional de Desenvolvimento Científico e Tecnológico) for financial support through PIBIC, Instituto Parreiras Horta for support and for help in the identification of Gram-negative microorganisms, and the team of technicians and auxiliary staff of DMO/CCBS/UFS.

\section{RESUMO}

\section{Microbiota da conjuntiva de indivíduos clinicamente normais que trabalham em ambiente hospitalar}

O objetivo deste trabalho foi a caracterização da microbiota da secreção conjuntival de profissionais hígidos do Hospital da Clínicas Dr. Augusto Leite, Aracaju, SE, Brasil. Foram colhidas amostras de secreção conjuntival de olhos clinicamente normais de 40 profissionais em 4 diferentes setores do hospital: Proctologia, Unidade Intensiva de Tratamento Geral, Enfermaria Masculina e Setor de Oncologia. As amostras foram inoculadas 
em ágar sangue, ágar Chapman, meio de Teague e ágar Sabouraud dextrose com cloranfenicol. As bactérias mais frequentemente isoladas de todos os setores foram Staphylococcus epidermidis (45,0\%) e Bacillus sp (29,0\%). As menos frequentes foram Proteus sp (6,1\%), Staphylococcus aureus (4,1\%), Enterobacter sp (4,1\%), Alcaligenes sp (4,1\%), Citrobacter sp (2,1\%), Moraxella sp (2,1\%) e Proteus mirabilis $(2,1 \%)$. Fungos não foram isolados. Estes resultados confirmam uma contaminação contínua do saco conjuntival desses profissionais pelo ambiente externo, evidenciando a importância dos mecanismos locais de defesa, que devem estar intactos na prevenção contra a fixação e a invasão desses microrganismos.

Palavras-chave: microbiota conjuntival, ambiente hospitalar, Staphylococcus epidermidis, Staphylococcus aureus.

\section{REFERENCES}

1. Castro, S.V. Anatomia Fundamental, $3^{\mathrm{a}}$ ed., Mc Graw-Hill do Brasil, São Paulo, 1985.

2. Christensen, J.N.; Fahmy, J.A. The bacterial flora of the conjunctival anophthalmic socket in glass prothesis-carriers. Acta Ophthalmol., 52(6): 801-809, 1974

3. Elander, T.R. et al. Microbial Changes in the Ocular Enviroment with Contact Lens Wear. CLAO J., 18(1): 53-55, 1991.

4. Fahmy, J.A. et al. Bacterial flora of the normal conjunctiva. Acta Ophtalmol., 53(2): 237-253, 1975.

5. Garg, S.P. et al. Conjunctival microbial flora in leprosy. Indian J. Leprosy, 62(1): 39-44, 1990.
6. Gregório, C.E.; Feitosa, V.L.C.; Candido, A.L.; Oliveira, M.I.M.P. Estudo da microbiota e dos tipos celulares encontrados na secreção conjuntival de olhos clinicamente normais. Aracaju,1992, 45p. (Monografia de Conclusão de Curso Apresentado ao Departamento de Medicina, Centro de Ciências Biológicas e da Saúde/UFS).

7. Haessaert, S.P. Clinical Manual of Ocular Microbiology and Cytology, Mosby Year Book, St. Louis, 1993, 134p.

8. Jawetz, E.; Melnick, J.L.; Adelberg, E. Microbiologia Médica, 20ª ed, Guanabara Koogan, Rio de Janeiro, 1995, 524p.

9. Larkin, D.F.P.; Leeming, J.P. Quantitative alterations of the commensal eye bacteria in contact lens wear. Eye 5:70-74, 1991.

10. Leitch, E.C.; Harmis, N.Y.; Corrigan, K.M.; Willcox, M.D. Identification and enumeration of staphylococci from eye during soft contact lens wear. Optom. Vis. Sci., 75(4): 258-65, 1998.

11. Matsuura, H. Anaerobes in the bacterial flora of the conjunctival sac. Japanese J. Ophthalmol. 15(2): 116-124, 1971

12. Mc Natt, J. et al. Anaerobic flora of the normal human conjunctival sac. Arch. Ophthalmol., 96(8): 1448-1450, 1978.

13. Miller, S.J.H. Enfermidade dos Olhos de Parsons. Artes Médicas, São Paulo, 1981, 121-122p

14. Organizacion Panamericana de la Salud 1984. Manual de Atenção ocular Primária.

15. Ramachandran, L.; Sharma S.; Sankaridurg, P.R.; Vajdic, C.M.; Chuck, J.A.; Holden, B.A.; Sweeney, D.F.; Rao, G.N. Examination of the conjunticve microbiota after 8 hours of eye closure. CLAO J., 21(3): 195199, 1995

16. Scarpi, J.M. 1984. Microbiota fúngica da conjuntiva normal de trabalhadores no corte da cana-de-açúcar. São Paulo, 1984, (Dissertação de Mestrado. Escola Paulista de Medicina. UNIFESP).

17. Strmen, P.; Hlavackova, K.; Ferkova, S.; Vavrova, K.; Jakabovicova, E.; Vrastilova, M. Endophthalmitis after lens surgery. Cesk Slov Oftalmol. 54(3): 141-7. 1998.

18. Trabulsi, L.R. Microbiologia, $2^{\mathrm{a}}$ ed., Atheneu, São Paulo, 1989.

19. Willcox, M.D.; Power, K.N.; Stapleton, F.; Leitch, C.; Harmis, N; Sweeney, D.F. Potencial sources of bacteria that are isolated from contact lenses during wear. Optom Vis. Sci., 74(12): 1030-1038, 1997.

20. Zanon, U.; Neves, J. Infecções Hospitalares (Prevenção, Diagnóstico e Tratamento), MEDSI, Rio de Janeiro, 1987. 